Küresel Kriz Sonrasında Cari Açık ve Kredi Hacmi Arasındaki İlişki: Türkiye Örneği

\title{
Relationship between Current Account Deficit and Credit Volume after the Global Financial Crisis: The Case of Turkey
}

\author{
Asst. Prof. Dr. Sinem Yapar Saçık (Karamanoğlu Mehmetbey University, Turkey) \\ Ebubekir Karaçayır (Karamanoğlu Mehmetbey University, Turkey)
}

\begin{abstract}
An important macroeconomic variable, current account deficit as percentage of gross domestic product is considered as an indicator of an economic crisis when it is above $5 \%$. In the economies where current account deficit is a problem, source of current account deficit should be determined for the solution. In the case of an interaction between credit expansion and current account, policies using a credit mechanism can be applied to stabilize the current account balance. In order to determine the relationship between current account deficit and credit volume before and after the financial crisis, visual graphics based on data will be utilized. This paper analysis the cointegration, long and short run causality relationship between current account deficit and consumer credits for Turkey over the period 2004Q3-2013Q3. The results of Johansen cointegration test indicate a cointegration between these variables. The empirical results show that there is bidirectional long and short run casuality relationship among variables. After the financial crisis of 2008, the increase in credit expansion increased domestic consumption depending on imports causing deterioration in current account deficit. There are difficulties of low finance qualities of this current account deficit and the realization of structural transformation in favor of exports in short term. Targeting a continuing economic growth increases energy dependency and import of investment goods, so puts credit mechanism policies forward to fight with current account deficit. Limiting the credit volume more than necessary to reduce current account deficit can worsen the various macroeconomic variables.
\end{abstract}

\section{Giriş}

Önemli bir makro ekonomik değişken olan cari açık/GSYİH çoğu zaman \%5 düzeyinin üzerinde olduğunda ekonomik kriz göstergesi olarak kabul edilmektedir. Cari açığın sorun olduğu ekonomilerde çözümüne yönelik, oluşan cari açıkların kaynağının saptanması gerekmektedir. Cari açık probleminin çözümüne yönelik olarak, bu problemin nedenlerinin ortaya konulması önemlidir. Literatürde cari açığı döviz kuru, reel faiz oranı, ekonomik büyüme ve kredi hacmi gibi birçok değişken ile ilişkilendiren çok sayıda çalışma vardır. Kredi genişlemesi ile cari işlemler arasında bir etkileşimin olması halinde cari işlemler dengesinin sağlanmasına yönelik kredi mekanizması politikaları uygulanabilmektedir.

Türkiye'nin de içinde olduğu birçok gelişmekte olan ülke ekonomisinde dişa açılma süreci sonrasında gerçekleşen ekonomik krizlerin öncesi ve sonrasında benzer ekonomik gelişmeler yaşanmaktadır. Kriz yılı öncesinde sermaye giriş ve kredi genişlemesi artarak, cari işlemler dengesi kötüleşmektedir. Kriz yıllarında ise, sermaye çıkışları ve kredi daralması yaşanarak cari işlemler dengesinde iyileşme gerçekleşmekte, kriz yılları sonrasında da kriz yılı öncesine göre benzer yapıya geri dönülmektedir. Küresel kriz sonrasında da, sermaye girişi ve kredi genişlemeleri yurtiçi talep kaynaklı ekonomik büyümeye bağlı olarak, cari işlemler dengesinde açıklara neden olmakta ve ekonomik kırılganlığı arttırmaktadır.

2008 küresel krizi sonrası Türkiye ekonomisi yurt içinde kolay ve ulaşılabilir kredi imkanları ile birlikte ekonomik büyüme sürecine girmiştir. Bu dönemde kredi genişlemesindeki artış ithalata bağımlı iç tüketimi arttırarak cari açı̆̆ın artmasında etkili olmuştur. Yüksek cari açıkların ülkemizde yaşanan ekonomik krizlerde etkili olduğu kabul edilmektedir. Oluşan bu cari açıkların ise finansman kalitesinin düşük olması ve kısa dönemde dış ticarette yapısal dönüşümün ihracat lehine gerçekleşmesinin zorluğu bilinmektedir.

Ekonomik büyüme hedefleri doğrultusunda enerji bağımlılığı ve yatırım ve aramalı ithalatında artışın devam ediyor olması cari açıkla mücadele amacıyla kredi mekanizması politikalarını öne çıkarmıştır. Bankaların kredi hacminin gerekli ölçüde sınırlandırılmasına yönelik düzenlemeler, finansal kaynaklı olası ekonomik krizleri engelleyebileceği düşünülmektedir. Cari açığı azaltmak için kredi hacminin gereğinden daha çok daraltılması ise farklı makro ekonomik dengesizliklere neden olabilir. Piyasada egemen olan KOBİ'lere (Küçük ve Orta Ölçekli İşletmeler) sağlanan işletme kredilerini sınırlandıran politikalar, toplam üretimin azalmasına ve işsizliğin artmasına neden olabilir. 


\section{Literatür Taraması}

Literatürde, cari açık ve kredi hacmi arasındaki ilişkiyi inceleyen bazı çalışmalar kronolojik sıra gözetilerek özetlenmiştir. Telatar (2011), çalışmasında Granger nedensellik testi ile krediler ve cari açık arasındaki ilişkiyi test etmiştir. Türkiye ekonomisinin incelendiği bu çalışmada 2003-I ile 2010-IV çeyrek dönemi kapsayan seriler kullanılmıştır. Çalışma sonucunda toplam kredilerden cari açığa doğru anlamlı bir nedensellik ilişkisine ulaşılamazken, tüketici kredilerinden cari açığa doğru pozitif bir ilişki bulgusuna ulaşılmıştır. Munzam karşılık oranlarının krediler açısından selektif bir yaklaşım ile uygulanarak, tüketici kredilerinin azaltılması çalışmanın önemli politik tavsiyelerindendir.

TCMB (2011), çalışmasında çeşitli grafik ve analizler kullanılarak özellikle küresel kriz sonrasında cari açık ve krediler arasındaki ilişki saptanmaya çalışılmıştır. Banka kredilerinin eğilim anketine de başvurulan bu çalışmada küresel kriz sonrasında cari açık ile tüketici kredileri içerisinde başta taşıt kredileri olmak üzere güçlü bir ilişkinin varlığı ifade edilmiştir. Togan ve Berument (2011), çalışmada VAR (Vektör Autoregressive) modeli çerçevesinde sermaye hareketleri, krediler ile cari işlemler dengesi arasındaki ilişkileri analiz etmiştir. 2010 yılı için cari işlemler dengesi/GSYİH'nın artmasında etkili olan temel değişkenin sermaye hareketleri olduğu bulgusuna ulaşılmıştır.

Özülke (2011), çalışmasında 2005-2011 yılları arasında cari açık ile tüketici kredileri arasındaki ilişkiyi araştırmıştır. 2010 ve 2011 yıllarında yüksek cari açıkların kredi genişlemesi veya tüketici kredisi genişlemesinden kaynaklı olduğunu söylemek için yeterli kaynağın olmadığı bulgusuna ulaşılmıştır. Ferrero (2012), çalışmada birçok gelişmiş ve gelişmekte olan ülkeler için kredi faiz oranları ve koşullarına göre değişen konut fiyatları ile cari açık arasındaki ilişkiyi ifade etmiştir.

Göçer, vd, (2013), çalışmalarında Türkiye'deki yurtiçi kredi hacmi ile cari işlemler açığı arasındaki ilişkiyi araştırmıştır. 1992-I ve 2012-III çeyrek dönemi kapsayan seriler kullanılmış olup Carrion-i Silvestre (2009) çoklu yapısal kırılmalı birim kök testi ve Maki (2012) çoklu yapısal kırılmalı eşbütünleşme yöntemine başvurulmuştur. Çalışma sonucunda kredi hacmi artışı ile cari işlemler açığı arasında pozitif ve istatistiki olarak anlamlı bir ilişkinin var olduğu tespit edilmiştir.

BDDK (2013), çalışmada 2002 -2012 yılları arasında çeyrek dönemli veri seti ile uygulama yapılmıştır. Çalışmada eş bütünleşme, nedensellik testleri ve Vektör hata düzeltme modeline başvurulmuştur. Çalışma sonucunda cari açık ile bireysel krediler arasında uzun dönemli ve ters yönlü bir ilişki saptanmıştır. Bireysel krediler içerisinde cari açıkla en güçlü ilişki kredi kartlarında yaşanırken bunu sırasıyla konut ve ihtiyaç kredileri izlemiştir. Aizenman, vd, (2013) çalışmalarında 2005 ve 2012 yılları arasında çeyrek dönemler itibariyle 36 ülke için gayrimenkul değerlenmesi, cari açık ve kredi büyümesi arasındaki ilişkiyi araştırmıştır. Çalışma, küresel kriz öncesi ve sonrasında incelenen ülkeler için gayrimenkul değer artışı, cari açık ve kredilerdeki büyüme (cari açık ve kredilerin GSYİH'e oranı) arasında pozitif bir ilişkinin varlığını desteklemektedir.

Ganioğlu (2013), çalışmada gelişmekte olan ve gelişmiş ülkelerde cari işlemler dengesizlikleri ve hızlı kredi genişlemeleri ile yaşanan finansal krizler arasındaki ilişkiyi araştırmıştır. Çalışmada panel logit veri tekniği kullanılarak, 1970-2008 dönemini kapsayan seriler kullanılmıştır. Hem gelişmiş ülkelerde hem de gelişmekte olan ülkelerde cari işlem dengesizlikleri ve hızlı kredi genişlemesinin finansal kriz olasılığını arttırma konusunda güçlü olduğu bulgusuna ulaşılmıştır.

\section{Cari Açık ve Krediler İlişkisi}

Türkiye'de önemli düzeylere ulaşan cari açı̆̆ın yapısal kaynaklı olması ve ekonomik büyüme hedefleri nedeniyle kısa sürede çözülemeyeceği bilinmektedir. Yüksek faiz oranları nedeniyle sermaye girişinin yoğun olduğu dönemlerde TL' değerlenme dış ticaret açığını arttırmaktadır. Bu dönemlerde yapısal olarak var olan cari açık konjönktürel olarak da etkilenmektedir. Konjonktürel dalgalanmaların önüne geçilmesi makroekonomik dengelerin kötüleşmesini engellemek amacıyla önemlidir. Şekil-1'den anlaşılacağ üzere net açılan krediler ile cari açık arasında güçlü bir ilişkinin varlığı konjonktürel nedenlerden kaynaklı cari açığın sınırlandırılabilmesi için kredilerin önemli bir araç olduğuna işaret etmektedir. Kredi geri dönüşlerinin ideal düzeyde olması, ekonomik krize neden olan bozulmaların önlenmesi amacıyla kredi politikaları önemli gözükmektedir (Kara, vd, 2013).

Şekil-1 incelendiğinde net açılan krediler ve cari açık arasında ters yönlü paralel bir seyir söz konusudur. Ayrıca söz konusu eş anlı hareketin, net açılan tüketici kredileri ve enerjiden arındırılmış cari açık arasında da geçerli olduğu görülmektedir. Küresel krize yakın dönemde kredi genişlemesi ve cari açık hızlı bir şekilde artarken, küresel krizin yaşandığı yıl bu göstergelerde hızlı bir yön değiştirme, kredilerin azalma şoku ve cari işlemler dengesinde ciddi toparlanmalar gerçekleşmiştir. Küresel krizden hemen sonra kredi genişlemesi ve buna bağlı olarak cari işlemler dengesinde bozulmalar başlayarak, bu göstergeler küresel kriz öncesi döneme yakınsamıştır. 2010 yılı sonunda kredi genişlemesini sınırlandıran düzenlemeler cari açığın artışını kısa süreli olarak frenlemiş daha sonra ekonomik büyüme hedefleri doğrultusunda artan krediler cari açığın artmasında etkili olmuştur. 


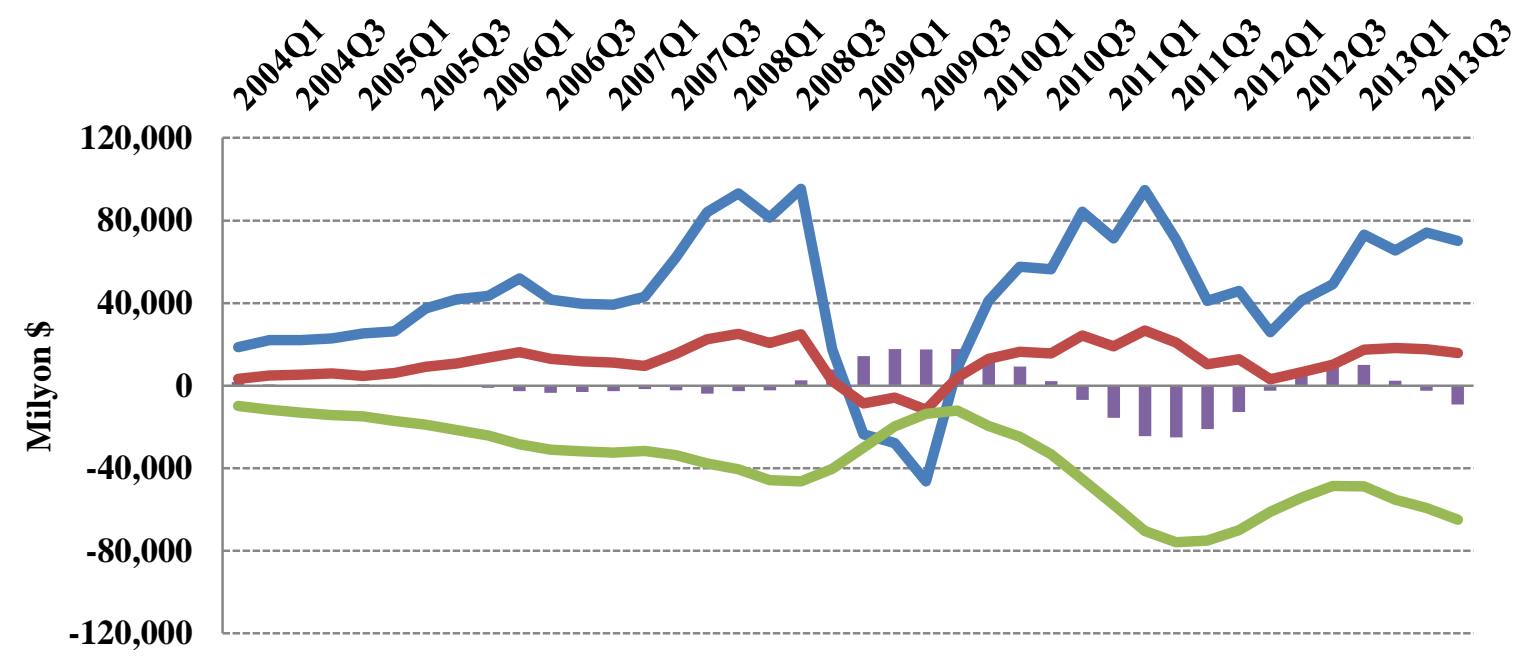

Enerji Hariç Cari Açık $\longrightarrow$ Toplam Krediler $\longrightarrow$ Tüketici Kredileri $\longrightarrow$ Cari Açı

Şekil 1: Net Açılan Krediler ve Cari İ̧slemler Dengesi (Çeyrek Dönemler İtibariyle Ylllıklandırılmış) Kaynak: BDDK, TCMB, TUIK

Toplam krediler içerisinde önemli bir paya sahip olan tüketici kredileri, bankalar tarafından kolay erişilebilir dış finansman kaynaklarına bağlı olarak artmaktadır. Yurt içi talepteki canlanma ve olumlu finansal süreç ile birlikte tüketici kredi talebinin, tüketici kredi arzı ile karşılanması tüketici kredi hacminde belirgin bir şekilde artış yaratmaktadır (Özlale, 2012). Kısa vadeli sermaye girişlerinin etkisinde değerlenen TL ise, tasarrufların azalmasında etkili olup tüketici kredisindeki genişleme ve düşük rekabet gücü kanalıyla ithalatın ve dolayısıyla cari açığın artmasında etkili olmuştur (Eşiyok, 2012).

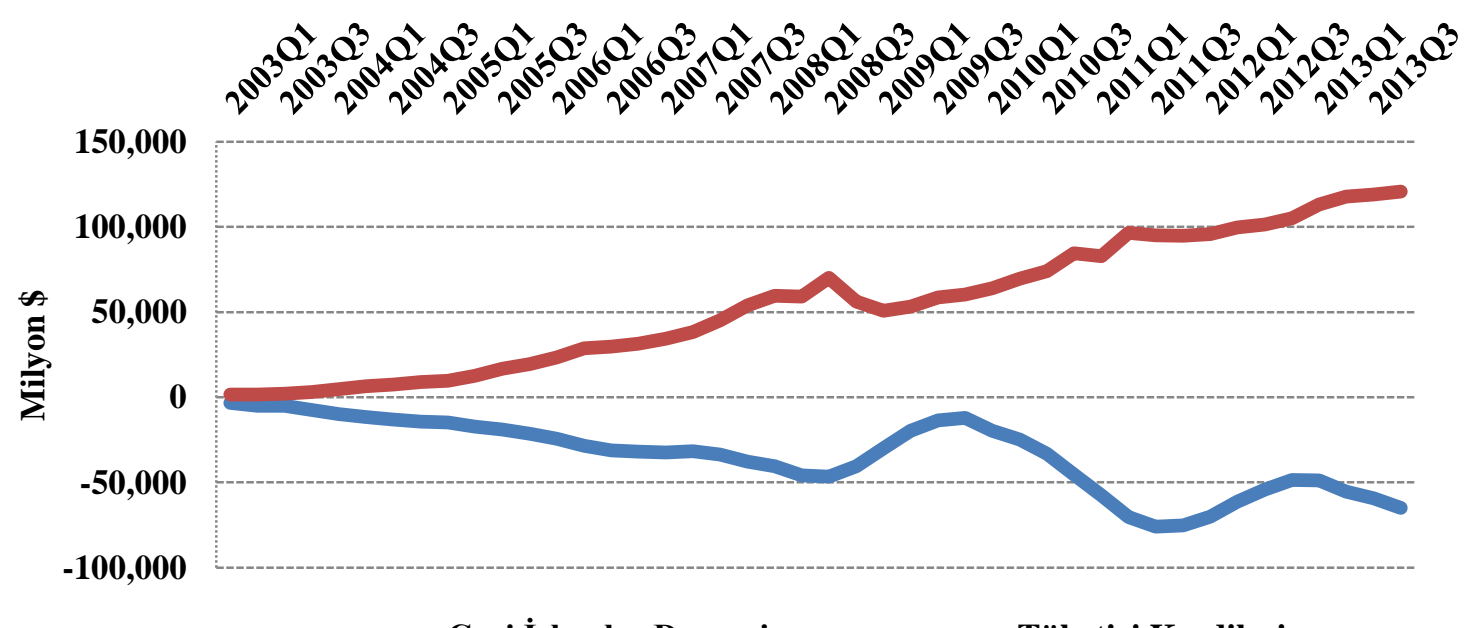

Şekil 2: Tüketici Kredileri ve Cari İ̧lemler Dengesi (Çeyrek Dönemler İtibariyle Ylllıklandırllmış) Kaynak: $T C M B, B D D K$

Tüketici kredileri bilindiği üzere geniş bir kitle tarafından talep edilmektedir. Tüketici kredilerinin düşük tutarlı ve piyasada bütün sektörlerde istihdam eden kişilerce talep edilmektedir. Bu durum, bankacıllk sistemi için riskin geniş kitlelere yayılarak, kredi takibini azaltmakta, tüketici kredi arzını ise arttırmaktadır. Şekil-2'de tüketici kredilerinin genel olarak küresel kriz yılı haricinde artış eğiliminde olduğu görülmektedir. Tüketici kredilerindeki bu artışın hane halkı ve firmaların ithalata bağlı tüketimlerini arttığı ve yurtiçi özel tasarrufların azalmasında etkili olarak cari açığı arttırıcı etkisi bulunmaktadır.

Cari açığın fazla verdiği dönemlerde, iç tasarruf birkimini arttırmak ve tüketimi azaltmak için özellikle tüketici kredilerinde kredi koşulları zorlaştırılmaktadır. Kredi kartı harcaması, ihtiyaç, taşı ve konut kredilerini içine alan tüketici kredilerinde uygulanan bu politikaların yansıması hanehalkı ve firmalara üzerinde çok yönlü olmaktadır. 


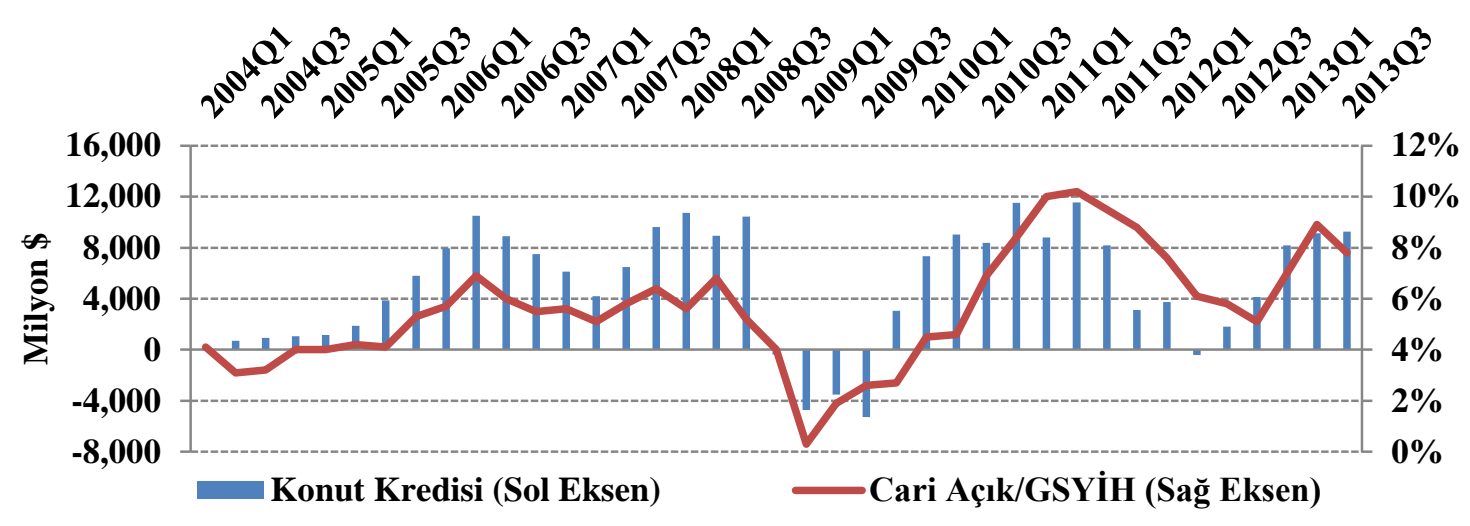

\section{Şekil 3: Net Açılan Konut Kredisi ve Cari Açı/ GSYIH (Çeyrek Dönemler İtibariyle Yıllıklandırılmış) Kaynak: $B D D K, O E C D$}

Şekil-3’te görüldüğü üzere tüketici kredileri içerisinde önemli paya sahip konut kredileri, cari açık /GSYIH ile özellikle küresel kriz sonrası yıllarda paralel bir seyir izlemiştir. Küresel krizden sonra, faiz indirimleri ve konut kredilerini teşvik edici düzenlemeler, özel kesim tasarruf yatırım açı̆̆ının artmasına neden olarak cari açık/ GSYIH'da artış meydana getirmektedir (Eğilmez, 2013). Kredi tutarının teminat olarak alınan konutun değerine oranı $\% 75$ 'e yükseltildiği 2010 yılı sonrasında ise konut kredilerinde yaşanan düşüşün cari işlemler dengesi/GSYiH'nın düşmesinde etkili olduğu görülmektedir (BDDK, 2014).

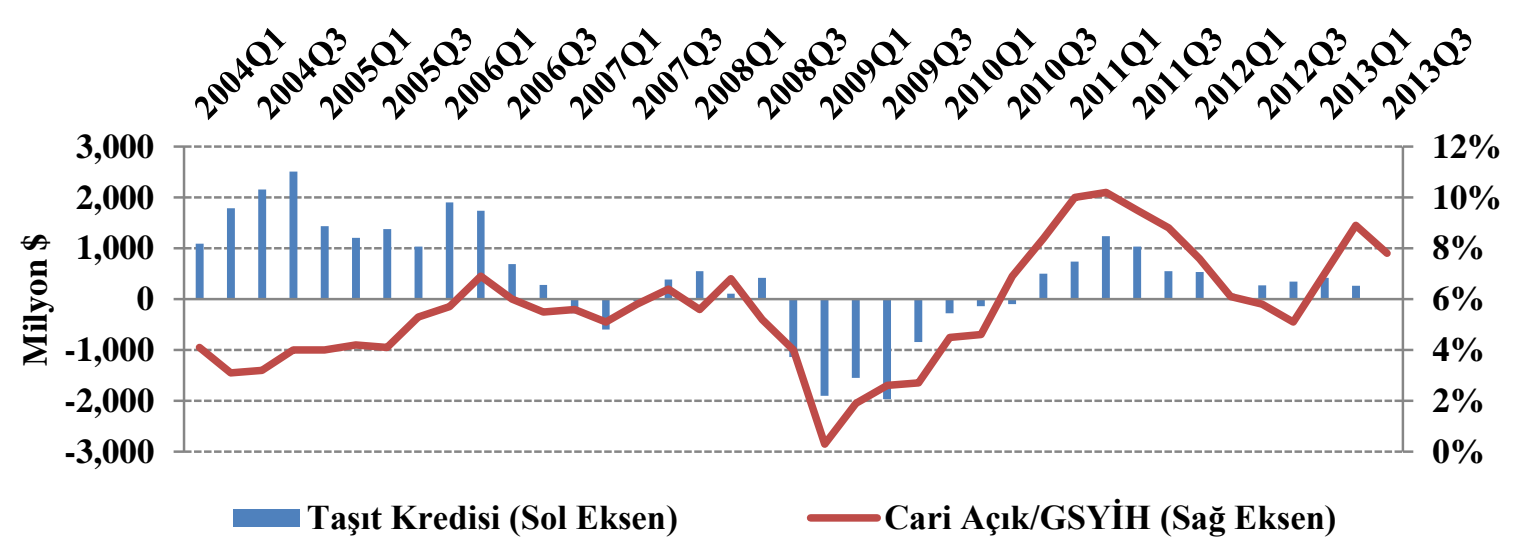

\section{Şekil 4: Net Açılan Taşıt Kredisi ve Cari Açık/ GSYİH (Çeyrek Dönemler İtibariyle Yıllıklandırılmış) Kaynak: $B D D K, O E C D$}

Şekil 4'te tüketici kredilerinde içerisinde yer alan taşıt kredileri ile cari açık /GSYIHH arasında paralel bir seyir gözlemlenmektedir. Taşıt kredileri ithalat içerisinde önemli paya ulaşan otomotiv sektörüne olan talebi doğrudan etkileyerek cari açık üzerinde etkili olmaktadır. Ayrıca taşıt kredilerinde yaşanan artış konut kredilerinde olduğu gibi özel kesim tasarruf açığına neden olarak cari açık/ GSYİH'nin artmasında etkili olduğu görülmektedir.

Şekil-5'te görüldüğü üzere küresel kriz sonrasında net açılan işletme kredilerinde hızlı bir artış yaşanırken, cari açık/GSYIH'de ise kötüleşme görülmektedir. 2011 y1lının ikinci çeyreğinde incelenen dönem içerisinde cari açık/GSYIH'nın en yüksek olması gerekiyor (\%10), net açılan işletme kredilerinin ise en yüksek (33 milyar \$) olduğu görülmektedir. Bu durum Şekil-3 ve Şekil-4'te tüketici kredileri içinde de benzer olduğu görülmektedir. Net açılan konut kredisi (11 milyar \$), net açılan taşıt kredisi (1.2 milyar \$) incelenen dönem içerisinde 2011 yılının ikinci çeyreğinde yüksek değerlere ulaştı̆̆ görülmektedir. Finansal istikrarın sağlanarak makroekonomik değişkenlerin kötüleşmesini engellemek amacıyla TCMB, kredilerin sınırlandırılmasına yönelik olarak para politikalarını uygulamak durumunda kalmıştır (TCMB, 2012).

Türkiye'de cari açığın nedenleri bilindiği üzere dışa açılma döneminden itibaren ithalatın ihracata göre oldukça hızlı artmasından kaynaklanmaktadır. Türkiye ekonomisinde özellikle 2003 yılından sonra ithal sanayi malları yerli aramalı mallarına ikame edilerek, sanayi üretimi ithalata bağımlı hale gelmiştir. (Yeldan, 2010). Toplam ithalatın hacminin içerisinde aramalı ithalatının ağılıkta olması, ithalattaki artışın girdi talebinden 
olduğunu göstermektedir. İhracat içerisinde ise ithalat girdi oranlarının yüksek olması bu dönemde ekonomik büyümenin aramalı ithalatı ile bağlantısını göstermektedir (Telatar ve Terzi, 2009). İşletme kredileri kullanarak ithal aramalı talep eden firmalar ise dolaylı olarak ekonomik büyümeye katkı yapmaktadır.

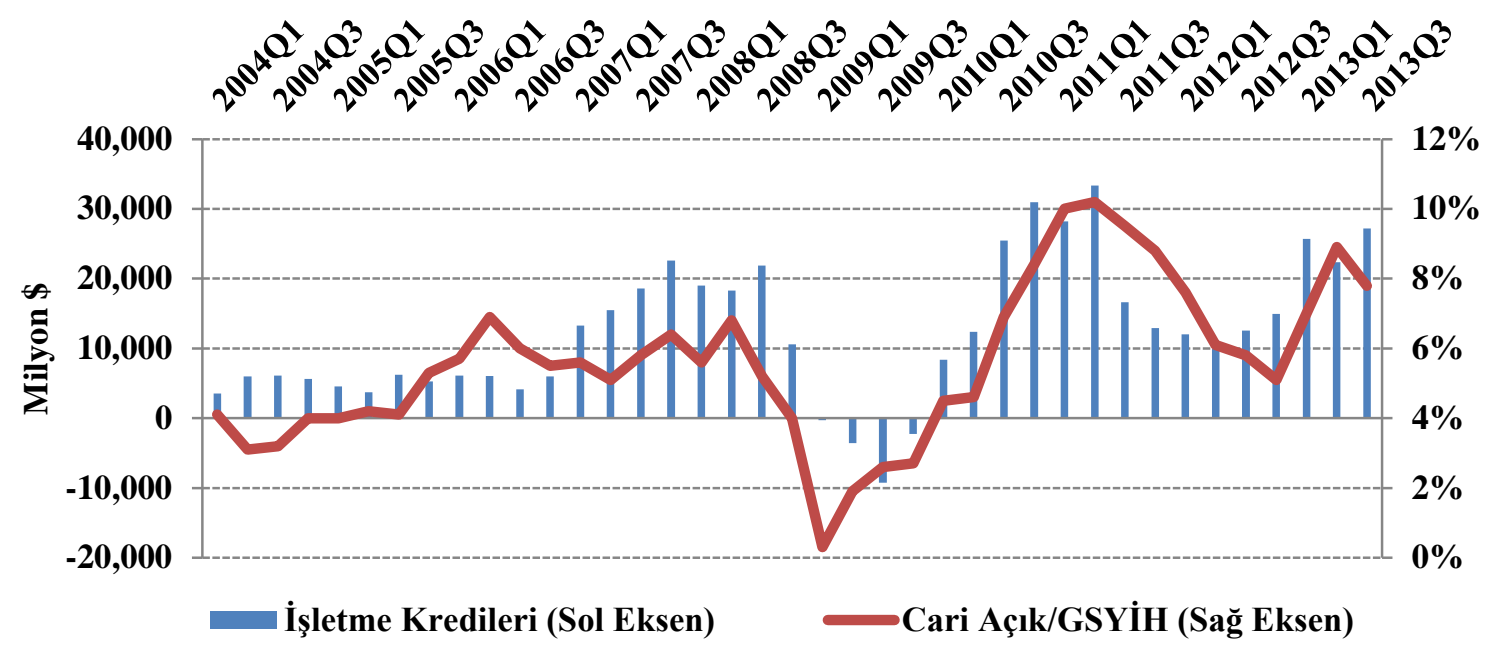

\section{Şekil 5: Net Açılan İşletme Kredisi ve Cari Açı/ GSYİH (Çeyrek Dönemler İtibariyle Yıllıklandırılmış) Kaynak: $B D D K, O E C D$}

Cari açığın işletme kredi hacmi ile gereğinden fazla sınırlandıran politikaların uygulanması durumunda sermaye kaynaklarının üretim faaliyetlerine aktarılması sorunu yaşanacaktır. Dış ticaret yapısından ötürü ise işsizlik, üretimin azalması gibi ekonomide bazı dengesizlikler oluşabilecektir. Bu nedenle cari açıkları azaltmak için işletme kredilerini sınırlamaya yönelik politikalar yerine üretim yapısını değiştiren, ithal girdi bağımlılığını azaltan yöntem ve teşvikler daha rasyoneldir.

Küresel ekonomik krizin ardından, Türkiye'nin de üye olduğu Basel Bankacıllk Denetim Komitesince, bankaların hızlı kredi genişlemesinin önüne geçebilmek amacıyla, 2010 yılında koruyucu ve sermaye tamponu uygulamalarını da içine alan Basel III hedefleri belirlenmiştir (TCMB, 2011). Sermaye tamponu uygulamasını tesis eden Basel III kriterlerinin uygulamasının küresel ekonomiye etkilerini en aza indirebilmek amacıyla uzun bir geçis süreci planlanmaktadır. Türkiye'de Basel III'e geçişs süreci 2013 yılında başlamış olup, tam anlamıyla uygulanması 2019 yılına kadar sürmesi beklenmetedir (BDDK, 2013).

Basel III kriterleri bankacılık kredileri üzerinde doğrudan etkili olurken kredi mekanizması ile cari işlemler dengesi üzerinde de dolaylı olarak etkili olması beklenmektedir. Kredi kullanabilmek için firmalar şeffaf yönetim anlayışını belirleyerek, kayıt dışından uzaklaşıp sermaye yeterliliğini arttırmak durumunda kalacaklardır. Bankalar ise firmalar arasında seçim yaparak, istenilen kriterleri sağlayan firmalara düşük maliyetli kredi imkanı tanıyacaktır (Kaderli, vd, 2013). Kredi arz ve talebinde bu şekilde dengenin sağlanması özellikle işletme kredi hacminin kısıtlanmasına yönelik politkaların oluşturduğu dengesizliklere göre piyasada daha çok etkinlik sağlayacaktır.

\section{Veri ve Metodoloji}

Cari açı/ GSYIH (CA) ve Net açılan Tüketici Kredileri/ GSYIH (TUK) modelde kullanılan değişkenlerdir. Türkiye ekonomisinde 2004III-2013III çeyrek dönemlik veri seti kullanılan bu çalışmada her iki değişken için census yöntemi ile mevsimsellikten arındırma işlemi yapılmıştır. CA değişkeni OECD, TUK değişkeni ise BDDK ve TCMB verilerinden alınmıştır.

Türkiye ekonomisinde cari açık ile toplam krediler içerisinde önemli paya sahip olan tüketici kredileri arasındaki ilişkinin sınanması amacıyla aşağıdaki ekonometrik metodlar kullanılmıştır.

- Birim Kök Testi

- Johansen Eşbütünleşme Testi

- Vektör Hata Düzeltme Modeline Dayalı Granger Nedensellik Analizi

\section{Ampirik Bulgular}

Zaman serilerinde sahte regresyon ihtimaline karşı birim kök testi yapılmaktadır. Bu nedenle Augmented Dickey- Fuller (ADF) ve Phillips-Perron (PP) testleri uygulanarak sonuçlar Tablo 1'de özetlenmiş̧tir. 


\begin{tabular}{|c|c|c|c|c|c|c|c|c|}
\hline \multicolumn{5}{|c|}{$\mathrm{ADF}$} & \multicolumn{4}{|c|}{$\mathrm{PP}$} \\
\hline \multirow[b]{2}{*}{ Değişkenler } & \multicolumn{2}{|c|}{ Seviye } & \multicolumn{2}{|c|}{ I. Fark } & \multicolumn{2}{|c|}{ Seviye } & \multicolumn{2}{|c|}{ I. Fark } \\
\hline & Sabit & \begin{tabular}{|l|} 
Sabit ve \\
Trend
\end{tabular} & Sabit & $\begin{array}{l}\text { Sabit ve } \\
\text { Trend }\end{array}$ & Sabit & $\begin{array}{l}\text { Sabit ve } \\
\text { Trend }\end{array}$ & Sabit & \begin{tabular}{|l|} 
Sabit ve \\
Trend
\end{tabular} \\
\hline $\mathrm{CA}$ & -1.6031 & $-3.1466(2)$ & $-4.9660 *$ & $-4.8709 *$ & $-1.9235(2)$ & $-2.3082(2)$ & $-4.9599(2)^{*}$ & $-4.8709 *$ \\
\hline TUK & -2.6602 & -2.7783 & $-6.6870 *$ & $-6.6017 *$ & $-2.7046(1)$ & $-2.8316(1)$ & $-6.6822(1) *$ & $-6.5975(1)^{*}$ \\
\hline
\end{tabular}

\section{Tablo 1: Birim Kök Testi Sonuçlart}

ADF ve PP testinde CA ve TUK değişkenleri düzey değerlerinde durağan çıkmazken, birinci farkı alındıktan sonra durağan hale gelmiştir. Tüm değişkenlerin birinci derecede durağan olması eşbütünleşme testinin uygulanabilmesine imkan vermektedir. Değişkenler arasında uzun dönem ilişkinin sınanması, eşbütünleşme testinin uygulanmasını gerektirmektedir. Eşbütünleşme testine yönelik olarak öncelikle Tablo 2'de optimum gecikme uzunluğu seçilerek VAR modeli tahmin edilmiştir.

\begin{tabular}{|c|c|c|l|l|l|l|}
\hline Gecikme & LogL & LR & FPE & AIC & SC & HQ \\
\hline 0 & 198.0402 & NA & $4.68 \mathrm{E}-08$ & -11.2023 & -11.11342 & -11.17162 \\
\hline 1 & 236.0056 & 69.42246 & $6.72 \mathrm{E}-09$ & -13.14318 & -12.87655 & -13.05114 \\
\hline 2 & 243.9265 & $13.57854^{*}$ & $5.39 \mathrm{e}-09^{*}$ & $-13.36723^{*}$ & $-12.92284^{*}$ & $-13.21382^{*}$ \\
\hline 3 & 246.5301 & 4.16576 & $5.88 \mathrm{E}-09$ & -13.28743 & -12.66529 & -13.07267 \\
\hline 4 & 251.6264 & 7.571688 & $5.59 \mathrm{E}-09$ & -13.35008 & -12.55019 & -13.07396 \\
\hline
\end{tabular}

* Belirlenen uygun gecikme uzunluğu

\section{Tablo 2: Var Modeli Gecikme Uzunluğu Belirleme Kriter Sonuçları}

LR (Likelihood Ratio), FPE (Final Prediction Error), AIC (Akaike Information Criteria), SC (Schwarz), HQ (Hannan Quinn) kriterlerine göre optimum gecikme uzunluğu 2 olarak belirlenmiştir. CA ve TUK arasında uzun dönemli ilişkinin varlığını tespit etmek için Johansen eşbütünleşme testi kullanılmış olup test sonuçları Tablo 3 'te sunulmuştur.

\begin{tabular}{|l|l|l|l|l|l|}
\hline Hipotez & Özdeğerler & İz İstatistiği & $\begin{array}{c}\text { İz Kritik } \\
\text { Değer (\%5) }\end{array}$ & $\begin{array}{c}\text { Maximum özdeğer } \\
\text { istatistiği }\end{array}$ & $\begin{array}{c}\text { Max Kritik } \\
\text { Değer (\%5) }\end{array}$ \\
\hline H0:r=0 & 0.500661 & 32.48285 & 20.26184 & 25.69536 & 15.8921 \\
\hline H0: r $\leq 1$ & 0.167603 & 6.787491 & 9.164546 & 6.787491 & 9.164546 \\
\hline \multicolumn{2}{|r}{ r: Eşbütünleşme vektör sayısını ifade etmektedir } \\
\hline
\end{tabular}

Tablo 3: Johansen Eşbütünleşme Test Sonuçları

Johansen eşbütünleşme testi sonucuna göre, en fazla bir eşbütünleşme vektörü olduğunu öngören hipotez $\% 5$ anlamlılık düzeyinde, iz istatistiği ve maksimum özdeğer istatistiğinin kritik değerlerden küçük çıkması nedeniyle reddedilememektedir. Bu sonuç uzun dönemde serilerin birlikte hareket ettiklerine yönelik bulguya işaret etmektedir. Değişkenler arasında, CA değişkenine göre normalize edilmiş eşbütünleşme ilişkisinden elde edilen paremetre tahminleri Tablo 4'te sunulmuştur.

\begin{tabular}{|c|}
\hline $\mathrm{CA}=0.0348+4.1981 \mathrm{TUK}$ \\
$(0.0115) \quad(0.4922)$
\end{tabular}

Tablo 4: Eşbütünleşme ilişkisinin tahmini

\begin{tabular}{|c|c|c|c|}
\hline \multirow{3}{*}{ Bağımlı değişken } & \multirow{2}{*}{\multicolumn{2}{|c|}{$\begin{array}{l}\text { K1sa dönem nedensellik } \\
\text { Açıklayıcı değişken }\end{array}$}} & \multirow{3}{*}{$\begin{array}{c}\text { Uzun dönem nedensellik } \\
\text { Hata Düzeltme Katsayısı ECT(-1) }\end{array}$} \\
\hline & & & \\
\hline & $\mathrm{D}(\mathrm{CA})$ & D(TUK) & \\
\hline $\mathrm{D}(\mathrm{CA})$ & & $\begin{array}{l}3.634897 \\
{[0.0566]^{* * *}}\end{array}$ & $\begin{array}{c}-0.121549 \\
(-1.88308)^{* * *}\end{array}$ \\
\hline $\mathrm{D}(\mathrm{TUK})$ & $\begin{array}{l}4.743607 \\
{[0.0294]^{* *}}\end{array}$ & & $\begin{array}{c}0.174728 \\
(2.91317)^{*}\end{array}$ \\
\hline
\end{tabular}

$\mathrm{t}$ değerleri parantez içerisinde, olasılık değerleri köşeli parantez içerisinde yer almaktadır. *,**,** sırasıyla $\% 1, \% 5, \% 10$ anlamlılık düzeyinde nedensellik olduğunu göstermektedir.

Tablo 5: VECM modeline dayall Granger nedensellik testi sonuçlart

Elde edilen sonuçlara göre TUK değişkeninin işareti pozitif ve \% 1düzeyinde istatistiksel olarak anlamlıdır. Uzun dönemde Türkiye'de tüketici kredilerindeki artışın cari açığın artmasında etkili olduğu bulgusuna 
ulaşı1mıştır. TUK değişkeninde 1 birimlik artış CA değişkenini ortalama olarak 4.2 birim arttırdığı görülmektedir. Değişkenler arasında uzun dönemli bir ilişkinin bulunması neticesinde, değiş̧enler arasında nedenselliğin yönü ve vektör hata düzeltme modeli (VECM) oluşturtulabilmektedir. Eşbütünleşik serilerde, seriler arasında nedensellik analizinin VECM modeli ile yapılması uygun olup, VECM modeline dayalı Granger nedensellik test sonuçları tablo 5'te sunulmuştur.

Granger nedensellik testi sonucunda kısa dönemde nedensellik ilişkisinin, $\% 5$ anlamlılık düzeyinde CA değişkeninden TUK değişkenine ve \%10 anlamlllık düzeyinde TUK değişkeninden CA değişkenine doğru olduğu tespit edilmiştir. Kısa dönemde değişkenler arasında çift yönlü bir nedensellik ilişkisi vardır. Uzun dönemde ise değişkenlerin hata düzeltme katsayılarının istatistiki olarak anlamlı olması uzun dönemde değişkenler arasında çift yönlü nedensellik ilişkisinin var olduğu anlamına gelmektedir. Türkiye'de uzun ve kısa dönemde çift taraflı nedensellik ilişkisinin tespiti, tüketici kredilerindeki artışın cari açığı artırıcı etkisi olduğu gibi, cari açıktaki artışında tüketici kredilerini arttırıcı etkide bulunduğu anlamına gelmektedir.

\section{Sonuç}

Çalışmada Türkiye ekonomisinde krediler ile cari açı̆̆ın paralel seyri farklı grafiklerle incelenmiştir. Çalışmanın uygulama bölümünde ise cari açık ile toplam krediler içerisinde önemli paya sahip tüketici kredileri arasındaki ilişki, Türkiye ekonomisi için 2004III-2013III çeyrek dönemlik seriler kullanılarak sınanmıştır. Johansen eşbütünleşme testine göre cari açık ile tüketici kredilerinin uzun dönemde birlikte hareket ettikleri bulgusuna ulaşılmıştır. Eşbütünleşik bulunan bu değişkenler arasında nedensellik yönünü bulmak için yapılan vektör hata düzeltme testi ve bu teste bağlı granger testleri sonucunda değişkenler arasında kısa ve uzun dönemde çift yönlü nedensellik ilişkisi tespit edilmiştir.

Cari açık ile kredi hacmi arasındaki ilişkinin varlığı, cari açık gibi önemli bir sorunun çözümünde sadece kredi hacminin azaltılması politikasının etkili olacağı anlamına gelmemelidir. Yapısal nedenlerle var olan cari açık konjonkturel nedenlerden dolayı arttığı zaman finansal istikrarsızlıklara neden olarak, makro ekonomik dengelerde bozucu etki yaratmaktadır. Bu nedenle cari açı̆̆ın konjonktürel nedenlerle çözümüne yönelik olarak kredi politikası kullanılırken, yapısal bozukluklar için ise üretimde teknolojiyle dönüşümün yaşandığı katma değer yaratan sektörlere yatırım yapılmalıdır.

Konjonktürel nedenlerde artan cari açığın çözümüne yönelik, ülke içerisinde bankaların dönemselliğe bağlı olarak kullanacakları ilave sermaye tamponu, likidite yeterliliği ve risk bazlı olmayan kaldıraç uygulamalarını içeren Basel III'ün uygulanması ise son derece önemlidir. Bu kriterlerin uygulanması, küresel ticarete zarar vermeden ilgili yasal mevzuatın tamamlanması beklenmelidir. Basel I ve II'ne göre daha kapsamlı olan Basel III'ün mevcut ticari bankalarının yönetim anlayışlarının şekillenmesi ile birlikte finansal piyasalarda olumlu etki oluşturacağı düşünülmektedir.

Parasal otoriteler ve düzenleyici kuruluşlarca, ekonomik büyümenin iç talebe bağlı olduğu dönemlerde yoğun tüketime konu olan ürünlerde taksit sayısının azaltılmasının cari açıkta olumlu etkisi olacağ düşünülmektedir. Kredilerin sınırlandırılması, iç talebi azaltarak üretim ve tüketimi dengelemektedir. Kredi hacminin daraltılması ile iç tasarrufların arttırılmasının cari açıkların kapatılmasında etkili olacağı beklenmektedir.

Kredi hacmin sınırlandırılması uygulanmasının genel olarak olumlu sonuçlar üretebileceğinin yanında bir takım olumsuz sonuçları da beraberinde getireceği unutulmamalıdır. Tüketici kredilerin sınırlandırılmasının sektörde egemen olan KOBİ gelirleri ve buna bağlı üretim ve işsizliğe neden olarak bir takım dengesizlikler yaratabilir. Tüketici kredilerinin kısıtlanmasın bir diğer olumsuz etkisi ise ülke içerisinde tüketim alışkanlığının devam ediyor olmasıdır. Kredi sınırlandırılması nedeniyle tüketicilerin alışkanlıklarından vazgeçmemesi, üreticilerin ise satışlarını arttırmak istemeleri, geleneksel yöntemlerin ticarette ödeme aracı olarak kullanılmasında etkili olacaktır. Geleneksel ödeme araçlarının daha çok tercih edilmesi sonucunda riskin firmalar tarafından üstleneceği, bankaların aracı durumlarını kaybedeceği unutulmamalıdır.

Türkiye'de kredi kartı kullanıcı ve pos işyeri sayıları incelendiğinde, kredi kartının piyasada yoğun şekilde tercih edilen bir ödeme aracı olduğu görülmektedir. Kredi kartı kullanımını azaltma yönündeki uygulamalar tüketim alışkanlığı nedeniyle harcamaların azalmayarak çek, senet gibi geleneksel ödeme araçlarının tercihini arttıracaktır. Geleneksel ödeme araçlarının yaygın olarak kullanılması sonucunda piyasada bir takım belirsizlik ve olumsuz riskler oluşabilecektir.

Cari açık ve kredi genişlemesi finansal krizler ile yakından ilgili olup takip edilmesi gereken iki önemli göstergedir. Cari açık ile cari açığın kontrolü için uygulanacak kredi ve kredi çeşidi politikası öncesinde ekonomik kazanç ve kayıplar dikkate alınarak ayrıntılı ve geniş kapsamlı politik analizler yapılmalıdır. 


\section{Kaynakça}

- $\quad$ Aizenman, vd, 2013. "Real Estate Valuation, Current Account, and Credit Growth Patterns, Before and After the 2008-2009 Crisis", ADBI Working Paper Series, 429

- $\quad$ BDDK, 2014. Duyurular, https://www.bddk.org.tr/WebSitesi/turkce/Duyurular/BDDK_Kurul_Kararlari/88813980.pdf . Erişim Tarihi:20.03.2014

- Bankacılık Düzenleme ve Denetleme Kurumundan: Bankaların Özkaynaklarına İlişkin Yönetmelik .(2013). T. C. Resmi Gazete,28756, 5 Eylül 2013.

- BDDK, 2014. Kredi verileri, http://ebulten.bddk.org.tr/ABMVC/tr/Gosterim/Gelismis. Erişim Tarihi:21.03.2014

- Eğilmez, 2013. Kendime Yazılar, http://www.mahfiegilmez.com/2013/03/ic-tasarruflarla-cari-ackiliskisi.html. Erişim Tarihi:22.03.2014

- $\quad$ Eşiyok, 2012. "Türkiye Ekonomisinde Cari Açık Sorunu ve Nedenleri", Finans Politik ve Ekonomik Yorumlar, 49, s.63.

- $\quad$ Ferrero,2012. "House Price Booms, Current Account Deficit, and Low Interest Rates", Federal Reserve Bank of New York Staff Reports, 541

- Ganioğlu, 2013. "Rapid Credit Growth and Current Account Deficit as the Leading Determinants of Financial Crises", Economics, 35.

- Göçer, vd, 2013. "Kredi Hacmi Artışının Cari Açığa Etkisi: Çoklu Yapısal Kırılmalı Eşbütünleşme Analiz", Ístanbul Üniversitesi İktisat Fakültesi Ekonometri ve İstatistik Dergisi, 18, s.1.

- Kaderli, vd, 2013." Basel III ve Yeni Türk Ticaret Kanunu’nun KOBİ’lerin Finansman Sorunu Üzerindeki Muhtemel Etkileri" Ege Akademik Bakış, 13,s. 505.

- Kara, vd, 2013. "Türkiye İçin Makul Kredi Büyme Oranı Ne Olmalı" TCMB Ekonomi Notları.

- OECD, 2014. Current account balance/GDP statistics, http://stats.oecd.org. Erişim Tarihi:19.03.2014

- Özlale, 2012." Türkiye'de Tasarruf Açığının Nedenleri ve Kapatılması İçin Politka Önerileri", Bankacılar Degisi, 83, s.2.

- Özülke, 2011. " The Effect of Consumer Loans on the Current Account Balance in Turkey (2005-2011)", 13th International Conference on Finance and Banking.

- TCMB, 2011. Finansal İstiktar Raporu Aralık-2010, http://www.tcmb.gov.tr/yeni/evds/yayin/finist/finist11.php. Erişim Tarihi:15.03.2014

- $\quad$ TCMB ,2012. 2011-IV Ödemeler Dengesi Raporu, http://www.tcmb.gov.tr/research/odemeler/ODRapor_20114.pdf. Erişim Tarihi:12.03.2014

- TCMB, 2014. Ödemeler dengesi verileri, http://evds.tcmb.gov.tr. Erişim Tarihi:11.03.2014

- Telatar, 2011. "Türkiye'de Cari Açık Belirleyicileri ve Cari Açık - Krediler İlişkisi", Banakacılar Dergisi , 78 , s.22

- Telatar ve Terzi, 2009 . "Türkiye'de Ekonomik Büyüme ve Cari İşlemler Dengesi", Atatürk Üniversitesi İktisadi ve İdari Bilimler Dergisi, 23, s.119.

- Togan ve Berument, 2011." Cari İşlemler Dengesi , Sermaye Hareketleri ve Krediler", Bankacılar Degisi , 78 , s.3.

- TUIK, 2014. Enerji ithalatı verileri, http://tuikapp.tuik.gov.tr/disticaretapp/menu.zul

- Yeldan , 2010. Türkiye Ekonomisinde Dış Açık Sorunu ve Yapısal Nedenleri. Subaşat ve Yetkiner (Ed.), Küresel Kriz Çerçevesinde Türkiye'nin Cari Açık Sorunsalı içinde (ss.34-47), Efil Yayınevi, Ankara. 